\title{
Gene Expression of Wheat (Triticum aestivum) Aquaporins under PEG- Induced Dehydration
}

\author{
Mona M. Elseehy ${ }^{1}$ and Ahmed M. El-Shehawi ${ }^{1,2}$
}

\begin{abstract}
Plant aquaporin genes regulate water movement through cellular membranes and determine the plant water relationship and plant adaptation to different environmental stresses. The expression of three PIP genes and one TIP gene was studied in response to PEG-induced dehydration in four Egyptian commercial wheat varieties. Semiquantitative estimation of RNA level via cDNA synthesis and PCR was used. Results showed that variations among the four studied genes in wheat varieties under normal condition and in the presence of PEG. Under normal conditions, Misr1 exhibited the highest level of PIP1 expression, Sids1 exhibited the highest level of PIP2 and PIP3 expression, and Gemmiza7 exhibited the highest expression of TIP1. Under dehydration induced by PEG, all three PIP genes (PIP1, PIP2, PIP3) showed various levels of transcription downregulation. PIP1 gave the highest level of downregulation in all varieties. Sids1 showed the highest response to PEG-induced dehydration because under normal conditions it exhibited high PIP expression and low TIP expression, whereas under dehydration condition it showed high downregulation of PIP genes and high upregulation of the TIP gene. This would be related to its high adaptation to dehydration. Results of this study will enhance our understanding of plant aquaporin expression profile and utilizing this in improvement of plant tolerance to dehydration.
\end{abstract}

Key words: Wheat, aquaporins, gene expression, dehydration, PCR.

\section{INTRODUCTION}

Water regulates various plant biological processes including plant growth and development through its movement across membranes which are regulated by a group of membrane channel proteins (aquaporins). Aquaporins are a subgroup of the major intrinsic protein (MIP) family. Aquaporins are channel proteins present in all living organisms (Agre et al., 1998) forming membrane pores with six membrane-spanning domains and cytoplasmic N- and C- termini. One main structure feature of aquaporins is that they have two conserved NPA motifs usually located in the middle of the pore (Murata et al., 2000). Aquaporins transfer water bidirectionally across the membrane (Hub et al., 2008; Wang and Tajkhorshid, 2007). Two main types of aquaporins are well characterized. On type transfers water while the other transports various molecules, such as urea, glycerol, carbon dioxide, and ammonia (Maurel et al., 2008), even though, both types of aquaporins control the passive transport through biological membranes in all forms of life (Heller et al., 1980).

Plant aquaporins are distributed under five groups. The plasma membrane intrinsic proteins (PIP) which contain two subgroups (PIP1 PIP2) and the tonoplast intrinsic proteins (TIP). They are localized in the plasma and tonoplast membranes respectively. The nodulin26-like intrinsic proteins (NIPs) which is a homologue of GmNod26. It is found in prebacteroid membrane of nitrogen fixing nodules in soybean. The small basic intrinsic proteins (SIPs) that are mostly present in the endoplasmic reticulum, and the $\mathrm{X}$ intrinsic proteins (XIPs) (Chaumont et al., 2001; Sakurai et al., 2005; Danielson and Johanson, 2008). The main function of plant aquaporins is to regulate water movement between the plant and its environment and inside the plant as well. They are responsible for about $95 \%$ of the water transfer through the plasma membranes (Henzler and Steudle, 2004). They generally can regulate water movement across membranes in three major strategies that are their expression level, their trafficking after synthesis in the $\mathrm{ER}$, and the regulation of opening and closing the aquaporin channel.

Genome studies showed variations in abundance of aquaporin genes in different plant genomes. Zhang et al (2013) reported 66 GmMIPs in the soybean genome that represented the five subfamilies which contain aquaporins, glyceroporins, aquaglyceroporins to regulate its water relations (Zhang et al 2013). In cotton (G. hirsutum), the aquaporin family was found to include 71 aquaporin genes that consist of 28 PIPs, 23 TIPs, 12 NIPs, 7 SIPs, and 1 XIPs (Park et al, 2010). Tomato genome (Solanum lycopersicum) was reported to have 47 aquaporin genes that were distributed in the five subfamilies; PIPs, TIPs, NIPs, SIPs and XIPs (Reuscher et al 2013).

Expression of plant aquaporins differs greatly under different environmental conditions in different plant species. Under drought conditions, PIP aquaporin were found to be downregulated to prevent water loss.

\footnotetext{
${ }^{1}$ Department of Genetics, Faculty of Agriculture,

University of Alexandria, Alexandria, Egypt.

${ }^{2}$ Department of Biotechnology, Faculty of Science,

Taif University, Taif, Saudi Arabia.

Received June 4, 2015, Accepted June 22, 2015
} 
Strawberry (Fragaria vesca L.) genome was found to have ten PIP genes. Under drought stress, four PIP genes were downregulated in roots and leaves. This led to the suggestion that transcription of PIP aquaporins is altered in response to low water availability (Surbanovski et al, 2013). In another study, drought stress induced by $250 \mathrm{mM}$ mannitol changed the expression of most PIP genes in the aerial part of Arabidopsis (Jang et al., 2004). Different responses of aquaporin expression to water stress were observed in upland (drought-resistant) and lowland (droughtsensitive) rice (Lian et al., 2006). Therefore, it was suggested that different cultivars of the same species may respond differently to water stress by changing their aquaporin gene expression. Drought resistance is a limiting factor of wheat breeding production which is the most important food crop for the world. Several wheat aquaporin sequences have been deposited in the nucleotide database. The expression of wheat aquaporins has not been studied under stress conditions. Therefore, in this study, expression of four wheat aquaporin genes was investigated under dehydration condition.

\section{MATERIALS AND METHODS}

\section{Induction of dehydration}

Wheat seeds of seven varieties (Misr1, Giza168, Sakha94, Sids1, Gemmiza7, and Shandawel1) were germinated in $0.5 \%$ water agar containing $10 \%$ polyethylene glycol (PEG-6000) for 10 days (Table 1)
(Guo et al, 2013; Elsiddig et al, 2013). Four varieties (Misr1, Giza168, Sids1, Gemmiza7) only were able to grow in the presence of PEG so that they were used in this study. The same varieties were grown in water agar without PEG. Ten-day old shoots were collected, lyophilized under vacuum at $-60^{\circ} \mathrm{C}$, ground to fine powder, and used for RNA isolation.

\section{Primer design}

The nucleotide database at the National Center for Biotechnology Information (http://www.ncbi.nlm.nih.gov) was searched for wheat (Triticum aestivum) aquaporins cDNA sequences. Total of 29 accessions were obtained. Most of them are partial sequences, therefore 3 full length PIPs and 1 long partial TIP cDNAs were chosen for primer design. A pair of specific primers (forward and reverse) was designed on their respective wheat aquaporin cDNAs (Table 2) using primer3 plus software (http://biotools.umassmed.edu/cgibin/primer3plus/prime r3plus.cgi). Information of these primers is summarized in Table 2.

\section{RNA isolation}

Total RNA was isolated from 10 day old shoots grown in the presence or absence of $10 \%$ PEG. Ten mg of ground tissue was transferred into microfuge tube and one $\mathrm{ml}$ of QIAzol was added and mixed (QIAGEN Inc., Valencia, CA).

Table 1. Egyptian wheat (Triticum aestivum) varieties used in this study

\begin{tabular}{llll}
\hline $\begin{array}{l}\text { N } \\
\mathbf{O}\end{array}$ & Variety & Status & Characteristics \\
\hline 1 & Misr1 & New & $\begin{array}{l}\text { High tillers, resistant to rusts (stem rust in particular), 13.9\%Protein, yield } \\
\text { is 25 ArdabFed. }\end{array}$ \\
\hline 2 & Giza168 & Commercial & $\begin{array}{l}\text { Resistant to three rusts, heat and drought tolerant, 12\%protein, 21 } \\
\text { ArdabFed. }\end{array}$ \\
\hline 3 & Sids 1 & $\begin{array}{l}\text { Commercial, } \\
\text { (Upper Egypt) }\end{array}$ & $\begin{array}{l}\text { Resistant to yellow but susceptible to leaf rust, heat tolerant, salinity } \\
\text { tolerant, 13.2\% protein, 19 ArdabFed. }\end{array}$ \\
\hline 4 & Gemmiza 7 & Commercial & Resistant to yellow and stem rust, 12.9\% protein, 20 ArdabFed. \\
\hline
\end{tabular}

Table 2. Primer sequence used in this study, accession number, and the expected PCR product of wheat (Triticum aestivum) aquaporins

\begin{tabular}{|c|c|c|c|c|}
\hline Primer & Sequence, $5^{\prime} \rightarrow 3^{\prime}$ & Product, bp & Gene & Accession \\
\hline WPIP1F & ctacatgattgcgcagtgcc & \multirow{2}{*}{591} & \multirow{2}{*}{ PIP1 } & \multirow{2}{*}{ AF139814.1 } \\
\hline WPIP1R & gccgaactgaactgtcgaga & & & \\
\hline WPIP2F & gctcctactacgtgcggtac & \multirow{2}{*}{591} & \multirow{2}{*}{ PIP1 } & \multirow{2}{*}{ AF139815.1 } \\
\hline WPIP2R & acgtacgaatggacggtcac & & & \\
\hline WPIP3F & cttcgtgctcgtctactgca & \multirow{2}{*}{593} & \multirow{2}{*}{ PIP1 } & \multirow{2}{*}{ AF139816.1 } \\
\hline WPIP3R & actaaccacctgatcagcgc & & & \\
\hline WTIP11F & cgcttgcttttggtgttgga & \multirow{2}{*}{605} & \multirow{2}{*}{ TIP1-1 } & \multirow{2}{*}{ EU177566.1 } \\
\hline WTIP11R & tggagaagcggaggaggaag & & & \\
\hline ActinF & tgccaagaacagctcctcag & \multirow{2}{*}{480} & \multirow{2}{*}{ Actin } & \multirow{2}{*}{ AY145451.1 } \\
\hline ActinR & gaagcacttcctgtggacga & & & \\
\hline PolyT & $\mathrm{ttttttttttttttttttttt}$ & - & - & - \\
\hline
\end{tabular}


Chloroform, $0.3 \mathrm{ml}$, was added to the homogenate. The mixture was then shaken for $30 \mathrm{~s}$ followed by centrifugation at $4^{\circ} \mathrm{C}$ and $13000 \mathrm{rpm}$ for $20 \mathrm{~min}$. The supernatant was transferred to a new tube. One volume of isopropanol was added and mixed. Samples were centrifuged for $15 \mathrm{~min}$ at $4^{\circ} \mathrm{C}$ and $13000 \mathrm{rpm}$. RNA pellet was washed with $70 \%$ ethanol, briefly dried, and dissolved in DEPC water. The integrity of RNA was checked by agarose gel electrophoresis. RNA concentration and purity were determined at $260 \mathrm{~nm}$ and the OD260/280 ratio.

\section{Synthesis of cDNA}

Total RNA, $2 \mu \mathrm{g}$, was mixed with $0.5 \mathrm{ng}$ oligodT primer in a total volume of $11 \mu \mathrm{l}$ sterilized DEPC water. The mixture was incubated in the Multigene thermal Cycler (Labnet, USA) at $65^{\circ} \mathrm{C}$ for $10 \mathrm{~min}$ for denaturation. Then, $4 \mu \mathrm{l}$ of $5 \mathrm{X}$ RT-buffer, $2 \mu \mathrm{l}$ of 10 $\mathrm{mM}$ dNTPs and $100 \mathrm{U}$ M-MuLV Reverse Transcriptase (SibEnzyme Ltd. AK, Novosibirsk, Russia) were added and the total volume was brought to $20 \mu$ l by DEPC water. The mixture was then re-incubated in the thermal Cycler at $37^{\circ} \mathrm{C}$ for $1 \mathrm{~h}$, then at $90^{\circ} \mathrm{C}$ for $10 \mathrm{~min}$ to inactivate the enzyme. cDNA was used as template for PCR or kept at $-20^{\circ} \mathrm{C}$ until used.

\section{Semi-quantitative PCR}

Specific primers designed on the nucleotide sequence of wheat aquaporin accessions (Table 1) were used in PCR reactions to amplify aquaporin cDNA molecules. PCR was conducted in a final volume of 25 $\mu \mathrm{l}$ containing $1 \mu \mathrm{l} \mathrm{cDNA}, 1 \mu \mathrm{l}$ of 10 picomol of each primer (forward and reverse), and $12.5 \mu 12 \mathrm{X}$ PCR master mix (Promega Corporation, Madison, WI, USA). PCR was carried out using one cycle of initial denaturation at $94^{\circ} \mathrm{C}$ for 5 minute, followed by 35 cycles of denaturation at $94{ }^{\circ} \mathrm{C}$ for 1 minute, annealing at $55^{\circ} \mathrm{C}$ for $1 \mathrm{~min}$, and extension at $72{ }^{\circ} \mathrm{C}$ for $1 \mathrm{~min}$. This was followed by one additional cycle of final extension at $72^{\circ} \mathrm{C}$ for $7 \mathrm{~min}$. The expression of actin mRNA was tested using specific primers (Table 1) as a reference. PCR products were separated in $2 \%$ agarose gel in TAE buffer at 50 volt for 60 minutes in the presence of ethidium bromide. PCR products were visualized under UV light and photographed. Densitometeric analysis of band intensities was determined using NIH imageJ program (http://rsb.info.nih.gov/nih-imageJ).

\section{Estimation of expression level}

Percentage of expression level was calculated using the densitometeric digital data. Under normal conditions, the expression percentage of a specific aquaporin gene of the four wheat varieties was calculated as the percentage of the highest level of expression $(100 \%)$ for that gene. In the presence of PEG, expression percentage for a gene was estimated as a percentage of its corresponding expression estimate under normal condition.

\section{RESULTS}

Expression of wheat aquaporin genes was investigated under PEG-induced dehydration compared to their expression under normal condition. Specific primers designed on the wheat aquaporin cDNA sequences obtained from the nucleotide database (www.ncbi.nlm.nih.gov) were used to estimate the gene expression of 3 PIP genes (PIP1, PIP2, PIP3) and one TIP gene (TIP1) (Table 2).

\section{Expression of wheat aquaporin PIP genes}

Expression of wheat PIP1 was estimated using its specific primers. There was natural variation in PIP1 expression under normal conditions among the four wheat varieties (in the absence of PEG). Under normal conditions, Misr1 showed the highest PIP1 expression level which was considered as $100 \%$ (Table 3). Gemmiza7 showed the lowest level of expression (54\%) compared to Misr1 (Table 3), whereas Giza168 and Sids1 showed close level of expression (Figure 1a,c), $86 \%$ and $88 \%$ compared to Misr1 (Table 3). PEGinduced dehydration caused a substantial downregulation of PIP1expression. The four wheat varieties showed lower expression level, but there was less variation in PIP1 expression (Figure 1a,c). Expression of PIP1 in Misr1, Giza168, Sids1, and Gemmiza7 was $26 \%, 25 \%, 21 \%$, and $31 \%$ respectively of their expression level under normal conditions (Figure 1a, c, Table 3). Actin gene expression was estimated as a reference (Figure 1b). Gemmiza7 showed the lowest expression of PIP1 under normal conditions but it showed the least downregulation in response to PEG, while Sids1 exhibited the highest level of downregulation in response to PEG (Table 2).

Wheat PIP2 expression also showed natural variation among wheat varieties in the absence of PEG. Sids1 showed the highest level of expression (100\%) (Table 3). Misr1, Giza168, and Gemmiza7 showed close level of expression; $89 \%, 79 \%, 83 \%$, compared to Sids1 expression respectively (Figure 2a,c; Table 3). Also, PEG-induced dehydration caused downgegulation of PIP2. Misr1, Giza168, Sids1, and Gemmiza7 exhibited $85 \%, 65 \%, 68 \%$, and $58 \%$ of PIP2 expression under normal conditions (Figure 2a,c; Table 3). Misr1 showed the least downregulation of PIP2, whereas Gemmiza7 exhibited the highest level of downregulation (Table 3). Actin gene expression was estimated as a reference (Figure $2 b$ ). 


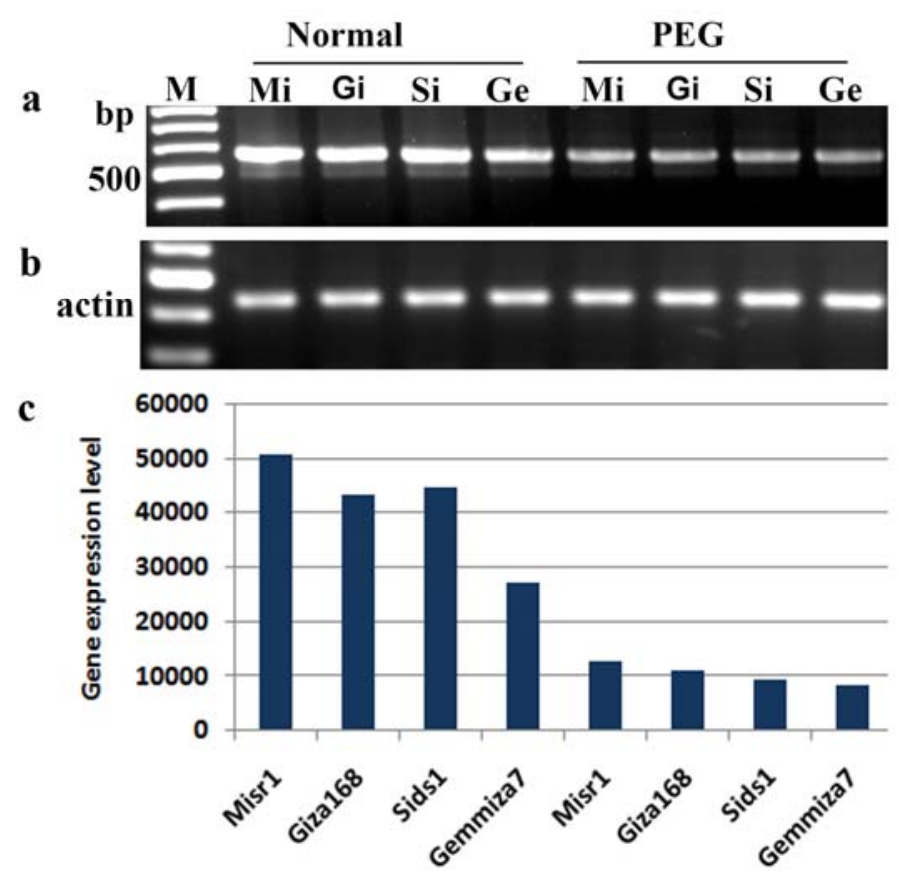

Figure 1. Wheat PIP1 expression. a. PIP1 expression; b. actin gene expression as reference. M: 100 bp ladder; Mi: Misr1; Gi: Giza168; Si: Sids1; Ge: Gemmiza7. c. Semiquantitative estimation of PIP1 expression of panel a.

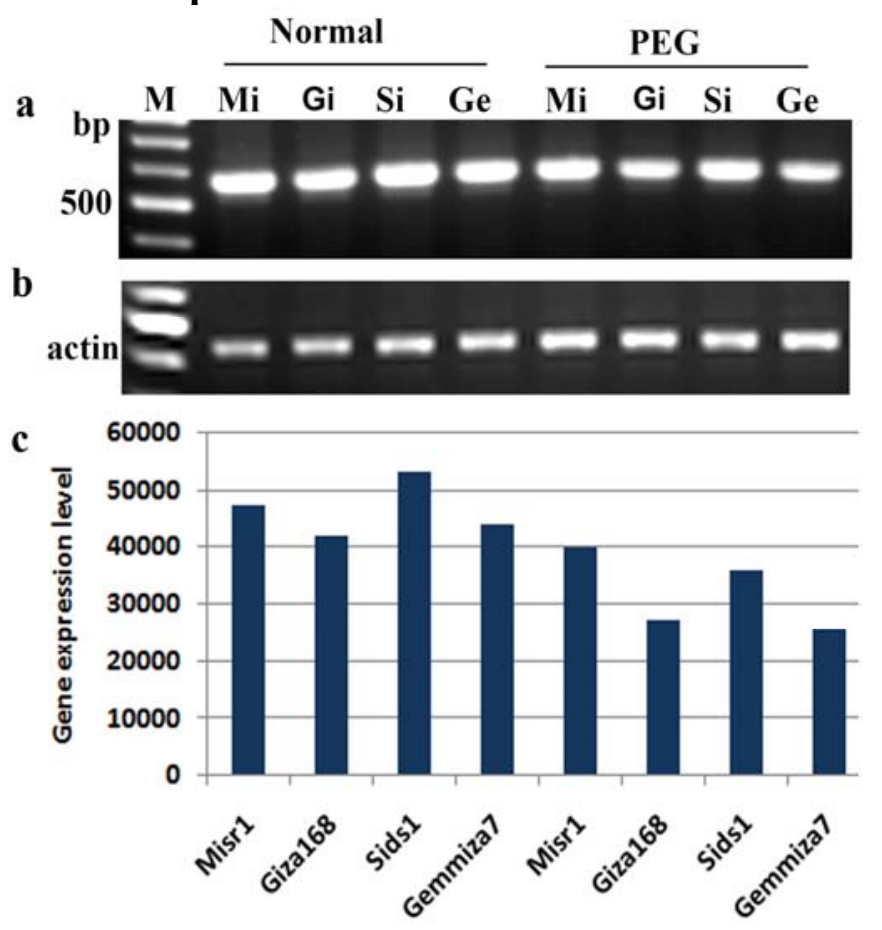

Figure 2. Wheat PIP2 expression. a. PIP2 expression; b. actin gene expression as reference. M: 100 bp ladder; Mi: Misr1; Gi: Giza168; Si: Sids1; Ge: Gemmiza7. c. Semiquantitative estimation of PIP2 expression of panel a. 
Table 3. Wheat aquaporin gene expression level (\%) under normal and PEG-induced dehydration.

\begin{tabular}{ccccccccc}
\hline \multicolumn{10}{c}{ Normal } & \multicolumn{4}{c}{ PEG-induced dehydration } \\
\hline Gene & $\mathbf{M i}$ & Gi & Si & Ge & Mi & Gi & Si & Ge \\
\hline PIP1 & 100 & 86 & 88 & 54 & 26 & 25 & 21 & 31 \\
\hline PIP2 & 89 & 79 & 100 & 83 & 85 & 65 & 68 & 58 \\
\hline PIP3 & 80 & 88 & 100 & 62 & 47 & 86 & 57 & 77 \\
\hline TIP1 & 83 & 82 & 40 & 100 & 203 & 240 & 357 & 202 \\
\hline
\end{tabular}

Mi: Misr1; Gi: Giza168; Si: Sids1; Ge: Gemmiza7.

Expression of PIP3 gene also exhibited variations in the presence or absence of PEG. Under normal conditions, Sids1 exhibited the highest level of expression (100\%), while Misr1, Giza168, and Gemmiza7 showed $80 \%, 88 \%$, and $62 \%$ of PIP3 expression in Sids1. In the presence of PEG, Misr1, Giza168, Sids1, and Gemmiza7 gave 47\%, 86\%, 57\%, and $77 \%$ of PIP3 expression under normal condition (Figure 3a,c; Table 3). Actin gene expression was estimated as a reference (Figure 3b). Misr1 showed the highest level of downregulation, whereas Giza168 exhibited the lowest level of downregulation of PIP3 in response to PEG.

\section{Expression of wheat aquaporin TIP1 gene}

On the contrary to the three studied PIP genes above, TIP1 gene showed upregulation in response to PEG treatment. Under normal condition, Gemmiza7 showed the highest level of TIP1 gene expression $(100 \%)$ and Misr1, Giza168, Sids1 gave 83\%, 82\%, $40 \%$ of Gemmiza7 TIP1 expression (Figure 4a, c; Table 3 ). In the presence of PEG, also Gemmiza7 gave the highest TIP1 expression. It showed $202 \%$ of its expression under normal condition. Misr1, Giza168, and Sids 1 showed $203 \%, 240 \%$, and $357 \%$ of TIP1 expression under normal condition. Gemmiza 7 showed the lowest level of TIP1 upregulation, while Sids1 showed the highest level of TIP1 upregulation (Figure 4a, c; Table 3).

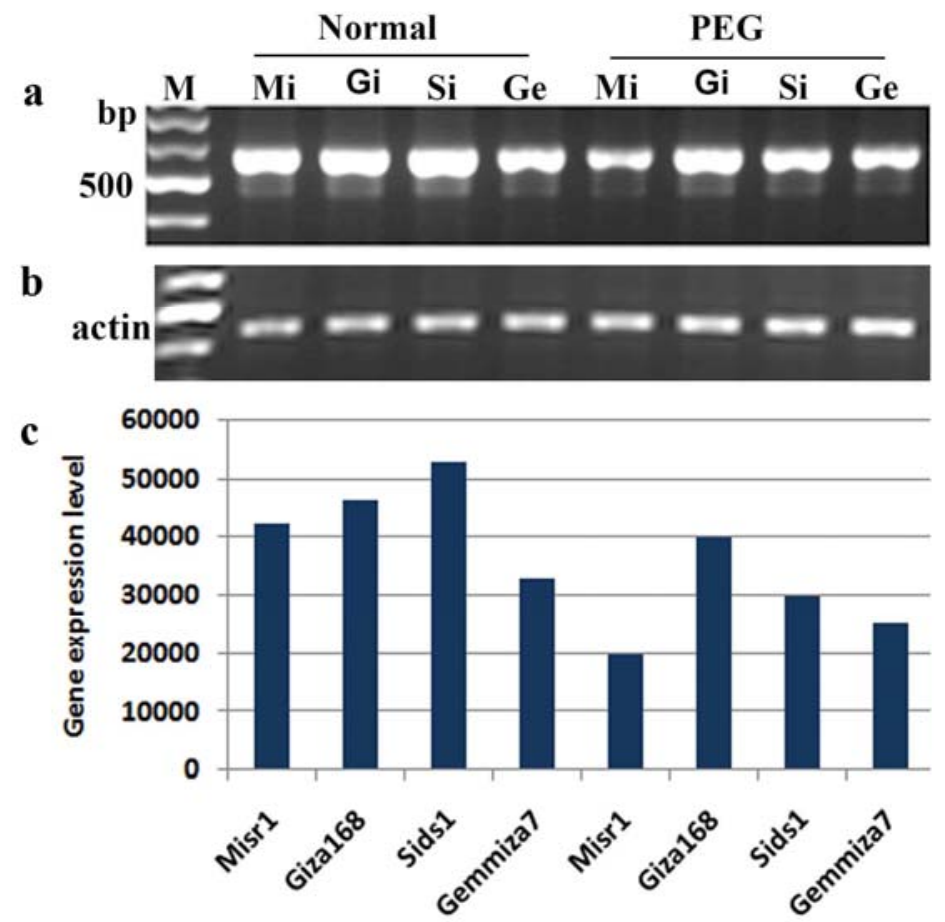

Figure 3. Wheat PIP3 expression. a. PIP3 expression; b. actin gene expression as reference. M: 100 bp ladder; Mi: Misr1; Gi: Giza168; Si: Sids1; Ge: Gemmiza7. c. Semiquantitative estimation of PIP3 expression of panel a. 


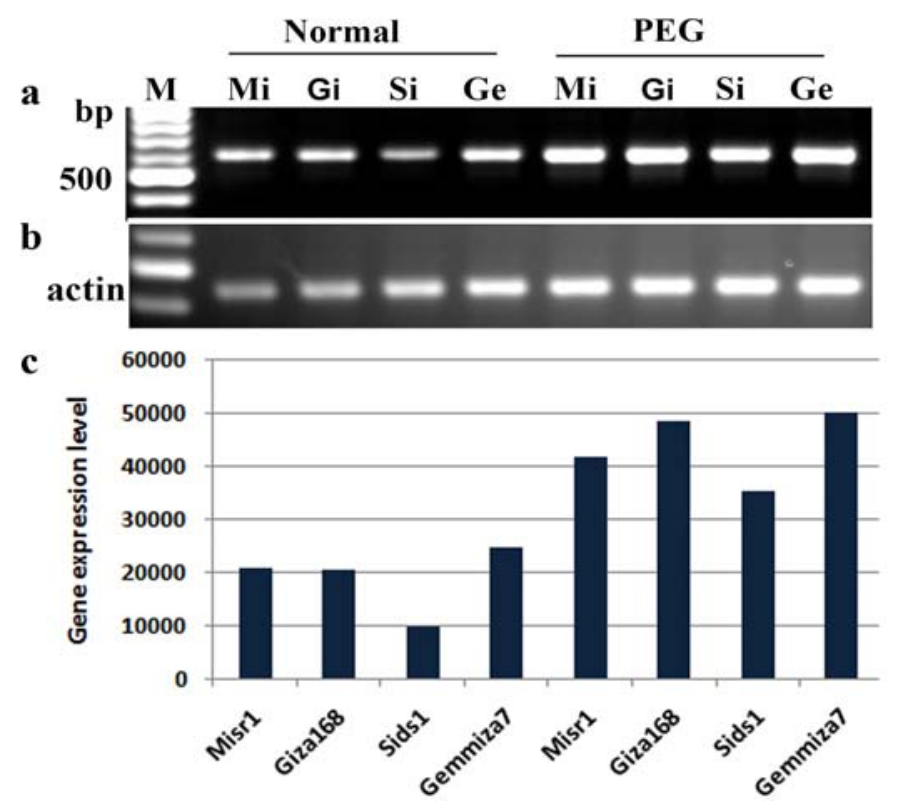

Figure 4. Wheat TIP1 expression. a. TIP1 expression; b. actin gene expression as reference. M: 100 bp ladder; Mi: Misr1; Gi: Giza168; Si: Sids1; Ge: Gemmiza7. c. Semiquantitative estimation of TIP1 expression of panel a. DISCUSSION

Gene expression of wheat aquaporin genes (PIP1, PIP2, PIP3, TIP1) was investigated under normal condition and in the presence of PEG as dehydration inducer. The four studied genes exhibited natural variations in their expression under normal condition as well as in the presence of PEG. The three PIP genes showed various levels of downregulation (Figure 1, 2, 3), while TIP1 showed different levels of upregulation (Figure 4) in the four wheat varieties in response to PEG treatment. There were different responses for every wheat variety to PEG treatment for individual genes. Also, there were different responses of individual genes toward PEG treatment. The three PIP genes were downregulated by PEG, whereas the TIP gene was upregulated (Figure 1,2,3,4, Table 3). Results obtained from this study agree with other previous reports. Various studies were conducted on water stressdependent expression of aquaporin genes (Maurel et al, 2002), especially the studies carried out on maize, rice, radish, and Arabidopsis. In these studies the expression of the whole aquaporin family was studied (Alexandersson et al, 2005; Boursiac et al, 2005; Guo et al, 2006; Jang et al, 2004; Lian et al, 2004; Maathuis et al, 2003; Suga et al, 2002; Zhu et al, 2005). General downregulation of most aquaporin transcription was reported under salt-stress in roots of Arabidopsis and maize (Alexandersson et al, 2005; Boursiac et al, 2005; Maathuis et al, 2003). Even though there is an overall downregulation of aquaporin gene in response to dehydration there was also specific upregulation of certain PIP transcripts in rice and Arabidopsis leaves (Alexandersson et al, 2005; Guo et al, 2006). For example, two upregulated transcripts in Arabidopsis were specifically expressed in aerial parts (Alexandersson et al, 2005). In barley (Hordeum vulgare) the increase in HvPIP1-6 transcripts in response to salt may indicate its role in promoting residual growth of the leaf under stress (Fricke et al, 2006). The downregulation of PIP aquaporin genes is thought to minimize water loss from plants to the dehydrated soil (Maurel et al 2008).

In this study, wheat TIP1 exhibited high level of upregulation. This also is in accordance with the explanation that under water stress vacuoles will work to keep the cellular water balance by mobilization of water from or into the vacuole (Maurel et al 2008). Sids1 variety exhibited high expression level of PIP1, PIP2, PIP3, whereas it showed high response to the PEG treatment. It showed low level of PIP1, PIP2, and PIP3, while it showed the highest level of TIP1. The combination of decreasing PIP gene expression and increasing TIP gene expression give indication that Sids1 is more adaptive to dehydration than other varieties under study.

Results of this study contribute to our understanding of plant aquaporin genes which can be utilized in enhancing drought tolerance of plants via modulating their expression. This will depend on the aquaporin gene and plant species under investigation. 


\section{REFERENCES}

Agre P, Bonhivers M, Borgnia MJ. (1998). The aquaporins, blueprints for cellular plumbing systems. Journal of Biological Chemistry 273, 14659-14662.

Alexandersson, E., Fraysse, L., Sjovall-Larsen, S., Gustavsson, S. and Fellert, M. (2005). Whole gene family expression and drought stress regulation of aquaporins. Plant Mol. Biol. 59:469-84

Boursiac, Y., Chen, S., Luu, D.T., Sorieul, M., van den Dries, N. and Maurel, C. (2005). Early effects of salinity on water transport in Arabidopsis roots. Molecular and cellular features of aquaporin expression. Plant Physiol. 139:790-805

Chaumont, F., Barrieu, F., Wojcik, E., Chrispeels, M.J., Jung, R., (2001). Aquaporins constitute a large and highly divergent protein family in maize. Plant Physiol., 125(3): 1206-1215. [doi:10.1104/pp.125.3.1206]

Danielson, J.A. and Johanson, U. (2008). Unexpected complexity of the aquaporins gene family in moss Physcomitrella patens. BMC Plant Biol., 8(1):45. [doi:10.1186/1471-2229-8-45]

Elsiddig, M.A., Baenziger, S., Dweikat, I. and El Hussein, A.A. (2013). Preliminary screening for water stress tolerance and genetic diversity in wheat (Triticum aestivum L.) cultivars from Sudan. Journal of Genetic Engineering and Biotechnology. 11: 87-94.

Fricke, W., Akhiyarova, G., Wei, W., Alexandersson, E. and Miller, A. (2006). The short-term growth response to salt of the developing barley leaf. J. Exp. Bot. 57:1079-95

Guo, L., Wang, Z.Y., Lin, H., Cui, W.E. and Chen, J. (2006). Expression and functional analysis of the rice plasmamembrane intrinsic protein gene family. Cell Res. 16:27786

Guo, R., Hao, W.P. and Gong, D.Z. (2013). Effects of water stress on germination and growth of wheat photosynthetic efficiency and accumulation of metabolites. http://dx.doi.org/10.5772/51205.

Heller, K.B., Lin, E.C. and Wilson, T.H. (1980). Substrate specificity and transport properties of the glycerol facilitator of Escherichia coli. J Bacteriol 144: 274-278. (PMID:6998951).

Henzler T, Ye Q, Steudle E. (2004). Oxidative gating of water channels (aquaporins) in Chara by hydroxyl radicals. Plant, Cell and Environment 27, 1184-1195.

Hub, J.S. and De Groot, B.L. (2008). Mechanism of selectivity in aquaporins and aquaglyceroporins. Proc Natl Acad Sci USA 105: 41198-1203. (doi: 10.1073/pnas.0707662104).

Jang JY, Kim DG, Kim YO, Kim JS, Kang H. (2004). An expression analysis of a gene family encoding plasma membrane aquaporins in response to abiotic stresses in Arabidopsis thaliana. Plant Molecular Biology 54, 713 725.
Lian HL, Yu X, Lane D, Sun WN, Tang ZC, Su WA. (2006). Upland rice and lowland rice exhibited different PIP expression under water deficit and ABA treatment. Cell Research 16, 651-660.

Lian, H.L., Yu, X., Ye, Q., Ding, X.S. and Kitagawa, Y. (2004). The role of aquaporin RWC3 in drought avoidance in rice. Plant Cell Physiol. 45:481-89

Maathuis, F.J., Filatov, V., Herzyk, P., Krijger, G.C. and Axelsen, K.B. (2003). Transcriptome analysis of root transporters reveals participation of multiple gene families in the response to cation stress. Plant J. 35:675-92

Maurel C, Verdoucq L, Luu DT, Santoni V. (2008). Plant aquaporins: membrane channels with multiple integrated functions. Annual Review of Plant Biology 59, 595-624.

Maurel, C., Javot, H., Lauvergeat, V., Gerbeau, P. and Tournaire, C. (2002). Molecular physiology of aquaporins in plants. Int. Rev. Cytol. 215:105-48

Murata, K., Mitsuoka, K., Hirai, T., Walz, T., Agre, P., Heymann, J.B., Engel, A. and Fujiyoshi, Y. (2000) Structural determinants of water permeation through aquaporin-1. Nature 407: 599-605. (PMID:11034202).

National Center for Biotechnology Information: http://www.ncbi.nlm.nih.gov

Park, W.; Scheffler, B.E; Bauer, P.J. and Campbell, B.T (2010). Identification of the family of aquaporin genes and their expression in upland cotton (Gossypium hirsutum L.). BMC Plant Biology 2010, 10:142

Sakurai J, Ishikawa F, Yamaguchi T, Uemura M, Maeshima M. (2005). Identification of 33 rice aquaporin genes and analysis of their expression and function. Plant and Cell Physiology 46, 1568-1577.

Suga, S., Komatsu, S. and Maeshima, M. (2002). Aquaporin isoforms responsive to salt and water stresses and phytohormones in radish seedlings. Plant Cell Physiol. 43:1229-37

Surbanovski N, Sargent DJ, Else MA, Simpson DW, Zhang H, et al. (2013) Expression of Fragaria vesca PIP Aquaporins in Response to Drought Stress: PIP Down-Regulation Correlates with the Decline in Substrate Moisture Content. PLoS ONE 8(9): doi:10.1371/journal.pone.0074945

Wang, Y. and Tajkhorshid, E. (2007) Molecular mechanisms of conduction and selectivity in aquaporin water channels. J Nutr 137 (6Suppl 1): S1509-S1515. (PMID:17513417).

Zhang DY, Ali Z, Wang CB, Xu L, Yi JX, et al. (2013) Genome-Wide Sequence Characterization and Expression Analysis of Major Intrinsic Proteins in Soybean (Glycine $\begin{array}{llll}\max & \text { L.). } & \text { PLoS ONE 8(2): } & \text { e56312. }\end{array}$ doi:10.1371/journal.pone.0056312

Zhu, C., Schraut, D., Hartung, W. and Schaffner, A.R. (2005). Differential responses of maize MIP genes to salt stress and ABA. J. Exp. Bot. 56:2971-81 


\section{الملخص الهري}

\section{تمبيرجينات الكولبورينف الفمح (Triticum aestivum) تهتظارف قص الماء المستحثه}

\section{بولملة البولي إيثيلين جليكل}

مني محمد الصيحي، لُممدمحمد الشهاوي

PIP3 بينما لُٔلهر الصف جميزة VI أعلي مستوي في تعبير الجين TIP1. تحت ظروف فص الماء المستحث بولنطة البولي إيثيلين جليكول ذأظهرت النتائج قص في مستوي

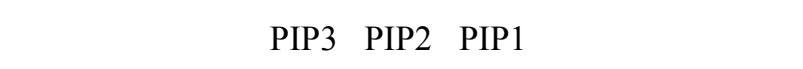
هو الألك إنغفاضا في أصنف القمح الأربعة تحت

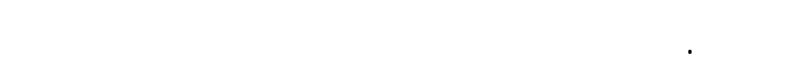

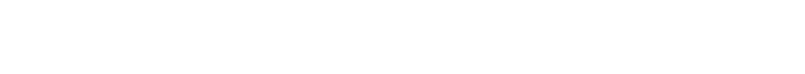

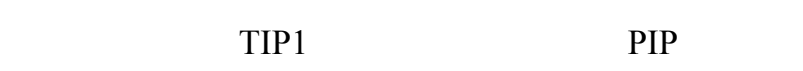
العادية، بينما لُٔلهر أعلي إنغفاض في تعبير جينات PIP وأعلي إرقاع في تعبير جين TIP تتحت ظروف فينما فينا الماء. ربما يدل ذلك علي قدرة هذا الصف العالية علي الأقلمة تحتظظروف قص الماء. نتائج هذه الدرلسةستسهر

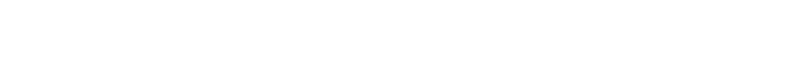
في تمسين تحمل النبل لظروف فقص الماء.
جينت الأكوالبورين لها دور كبير في تتظيم حركة الماء خلال الأغثية الخلوية وتحدد علاقة النبت بالماء وليستجابته

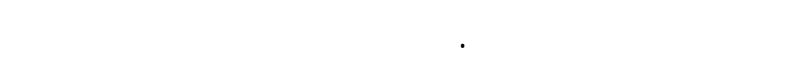

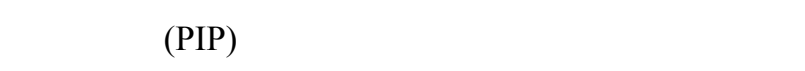
جينت الأكولبورين المنمجة في غثاء الفجوات (TIP) إلستجابة لقص الماء المستحث بِولنطة البولي إيثيلين

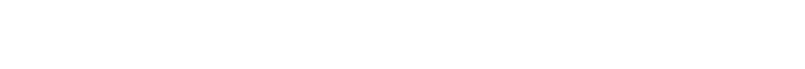

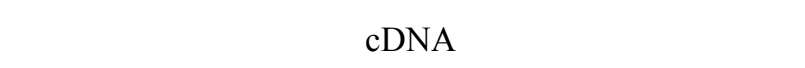
(PCR)

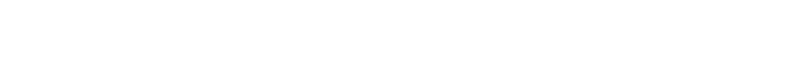
الدرلسة وذلك تحت الظروف الطبيعية وفي وجود البولي

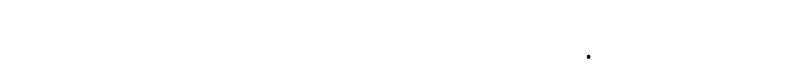

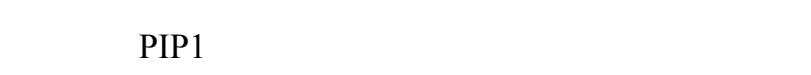

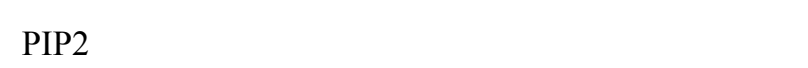

